\title{
Fungal and bacterial population from spent mushroom substrate used to cultivate tomato plants
}

\author{
População de fungos e bactérias presentes no composto pós-cultivo de cogumelos \\ utilizados como substrato em plantas de tomate
}

\author{
Tatiana Silveira Junqueira de Moraes $^{1}$ (D), Lívia Martinez Abreu Soares Costa ${ }^{1}$ (D), Thiago Pereira Souza ${ }^{1}$ (D), \\ Carolina Figueiredo Collela ${ }^{1}$ (D), Eustáquio Souza Dias ${ }^{1 *(\mathbb{D})}$
}

'Universidade Federal de Lavras/UFLA, Departamento de Biologia/DBI, Lavras, MG, Brasil

*Corresponding author: esdias@ufla.br

Received in April 23, 2020 and approved in June 26, 2020

\begin{abstract}
The production of tomato seedlings is conducted on commercial substrates with adequate properties for the good formation of the aerial part and root. The Spent Mushroom Substrate, or SMS, presents advantages over commercial substrates regarding the quality of the vegetable seedlings, which may be provided by the presence of a rich microbiota, bringing higher balance and competition with pathogenic microorganisms, in addition to the biological control of pathogens and nematodes. It is important to know the microbiota present in this material and its relation to the plant, in order for this association to occur in the best manner possible. This work had the objective of identifying the microbiota present in the rhizosphere of tomato seedlings produced in SMS of Agaricus subrufescens and Agaricus bisporus mushrooms, added or not with commercial substrate. The microbiota was analyzed by DGGE and the representative samples were sequenced in order to identify the species. Among the eukaryotes, the Chaetomium globosum, Arthrobotrys amerospora species were predominant in the A. subrufescens SMS, and Geastrum floriforme, Chrysosporium chiropterum, Pleurotus sp., and Trichosporon $\mathrm{sp}$. in the A. bisporus SMS. Prokaryotes are the most diverse group, suggesting a large number of species not yet classified or which sequences are not yet available.
\end{abstract}

Index terms: Agaricus sp.; Lycopersicon esculentum; seedling production; SMS.

\begin{abstract}
RESUMO
A produção de mudas de tomateiro é conduzida em substratos comerciais com propriedades adequadas para a boa formação da parte aérea e da raiz. O composto pós-cultivo de cogumelos ("Spent Mushroom Substrate" ou SMS) apresenta algumas vantagens em relação aos substratos comerciais para a qualidade das mudas de hortaliças, que podem ser proporcionados pela presença de uma rica microbiota, trazendo maior equilíbrio e maior competição com microrganismos patogênicos, além do controle biológico de patógenos e nematoides. É importante conhecer a microbiota presente nesse material e sua relação com a planta, para que essa associação possa ser feita da melhor maneira possível. Este trabalho teve como objetivo identificar a microbiota presente na rizosfera de mudas de tomate produzidas em SMS de cogumelos das espécies Agaricus subrufescens e Agaricus bisporus, acrescidos ou não de substrato comercial. A microbiota foi analisada por DGGE e amostras representativas de DNA foram sequenciadas para identificação das espécies. Entre os eucariotos, foram encontradas espécies de Chaetomium globosum, Arthrobotrys amerospora, predominantes no SMS de A. subrufescens, e Geastrum floriforme, Chrysosporium chiropterum, Pleurotus sp., e Trichosporon sp. no SMS de A. bisporus. Os procariontes apresentam maior diversidade, sugerindo um grande número de espécies ainda não classificadas ou cujas sequências ainda não estão disponíveis.
\end{abstract}

Termos para indexação: Agaricus sp.; Lycopersicon esculentum; produção de mudas; SMS.

\section{INTRODUCTION}

The tomato plant (Solanum lycopersicum) originates from Central and South America, consumed throughout the world, whose seedlings can be produced in different substrates, such as green coconut fiber, sawdust, rice husk and the spent mushroom substrate of Agaricus (Collela et al., 2019; Lopes et al., 2015). Spent mushroom substrate (SMS) refers to the biomass waste generated from mushroom production. Approximately, $5 \mathrm{~kg}$ of SMS is produced for each kilogram of fresh mushroom (Lin; Ge; Li, 2014; Zisopoulos et al., 2016). SMS residue is often discarded as a waste after harvesting mushroom in many countries (Chiu et al., 1998). SMS composition is very significant to be used as different applications, 
as bioremediation agents, feed supplements, substrates in agriculture, energy, wastewater treatment and metallic ions biosorption (Dong et al., 2017; Rinker, 2017; Qu et al., 2015). If appropriately treated, it constitutes an excellent alternative to the problem of discarding agricultural and agroindustrial residues (Hanafi et al., 2018; Rinker, 2017). The correct destination of the SMS is extremely important, since it must be discarded immediately by the producer to avoid problems of contamination and incidence of pests in the new cycles of cultivation. Furthermore, solid waste disposal is a growing problem worldwide and it is important to find alternatives to minimize this problem (Ashrafi et al., 2017; Lopes et al., 2015; Marques et al., 2014).

Lopes et al. (2015) reported the use of Agaricus subrufescens SMS in different proportions (0 to 100\%) for the production of tomato seedlings, not only evaluating the quality of the seedlings produced, but also their performance after transplanting. The use of SMS did not result in a better quality of the seedlings in relation to the commercial substrate, considering shoot mass, root mass, etc. However, the use of SMS positively affected the agronomic performance, since the seedlings produced in substrate with SMS presented a superior productivity in relation to the control. Considering the total tomato production, the higher the proportion of SMS used, the higher the tomato yield, and the better results were obtained in the substrate with $100 \%$ SMS. Another study about SMS as a growth medium for tomato seedlings showed that SMS provides a good growing medium for the seedlings, contributing to waste reuse in an environmental friendly way (Meng et al., 2018).

Among the different factors that may be involved in this process, we highlight the rich microbiota present in this type of substrate, which could influence the rhizosphere microbiota of the seedlings produced in it. This microbiota plays an extremely important role in protecting the plant against pathogenic microorganisms present in the soil, as well as nematodes, which are important parasites of tomato plants (Martínez-Medina et al., 2017). In addition, it is important to note that the isolation and identification of these microorganisms stimulates studies with the aim of using certain species for the control of nematodes in tomato cultivation (Dallemole-Giaretta et al., 2015).

Thus, it is important to know the microbiota present in the SMS of these species of mushrooms, as well as to compare the rhizosphere microbiota of seedlings produced in the SMS of different species of mushrooms and the commercial substrate. In addition to the traditional techniques of isolation, cultivation and identification of cultivable microorganisms, it is also important to use molecular techniques to identify them, in order to avoid underestimating the population present in the sample (Coughlan et al., 2015; Lubya et al., 2016). Different molecular techniques may be used for this purpose, such as microarrays, RT-PCR, DGGE and pyrosequencing (Hiraoka; Yang; Iwasaki, 2016; Srivastava et al., 2019). Each technique presents advantages and disadvantages, even varying in its reproducibility. Even pyrosequencing, which is recognized as the cutting edge technique today, may provide intermediate levels of reproducibility and is also susceptible to errors. Other techniques, simpler and older, such as TGGE and DGGE are considered to be highly reproducible. However, this does not affect the objectives of most of the studies for which the technique is used. Therefore, due to its simplicity and application potentialities, the DGGE technique was chosen for the present study.

In this work the microbiota present in the rhizosphere of tomato plants cultivated in the SMS of mushrooms of the species Agaricus subrufescens and Agaricus bisporus, with or without commercial substrate and compared with the commercial substrate (Tropstrato) were identified.

\section{MATERIAL AND METHODS}

The SMS samples, totaling 4 months from the inoculation of the substrate with the two species of Agaricus, were ground into smaller particles, aiming at a better texture of the substrate for the production of seedlings. The composition of the SMS consisted of bagasse, horse manure, rice straw, soybean meal, poultry litter, urea, potassium chloride, single super phosphate fertilizer, gypsum and peat moss. After cultivation, the SMS including the casing layer was thoroughly mixed, wetted and composted.

The seeds of tomato (Solanum lycopersicum), cultivar Santa Cruz Kada, were germinated in styrofoam tray, filled with commercial substrate (Tropstrato ${ }^{\circledR}$ ) for vegetables and submitted to irrigation twice a day. After 17 days of sowing, seedlings were transplanted into 1.5 liter pots. The SMS of the Agaricus mushrooms was used to compose the substrate for transplanting the tomato seedlings, in proportions of $50 \%$ or $100 \%$, in addition to the control (100\% Substrate Commercial [Tropstrato]). Five treatments were used: $100 \%$ A. subrufescens (AS100), $50 \%$ A. subrufescens $+50 \%$ Tropstrato (AS50), $100 \%$ A. bisporus (AB100), 50\% A. bisporus $+50 \%$ Tropstrato (AB50) and $100 \%$ Tropstrato (C).

Rhizospheric soil samples were collected once a week for eleven weeks. From these, samples from 
weeks $1,4,8,9$ and 11 were chosen. For the collection of the substrate samples, the plants were cut off and only the substrate trapped at the roots of the plants were collected. Its DNA was extracted using the Power Soil ${ }^{\circledR}$ DNA Isolation Kit (MoBio) following the manufacturer's instructions. For prokaryote DNA amplification reactions, primers $338 \mathrm{f}$ and $518 \mathrm{r}$ GC were used. For eukaryotes ITS1 and ITS2 GC primers were used. The GC clamp, when attached to the 5' end of one of the primers, is PCR amplified along with the DNA, and acts as a high denaturing resistance domain, which prevents the dissociation of the two DNA strands from single strands. Typically, the length of the GC clamp varies between 30 and 50 nucleotides.

PCR products were applied on $8 \%$ polyacrylamide gel, with a denaturing gradient of 35 to $50 \%$ for prokaryotes and 8 to $45 \%$ for eukaryotes. The electrophoresis was performed in a unit of DGGE D Code and the most prominent bands were amplified by PCR for later identification of the species, through sequencing of the ribosomal region. The amplicons sequencing was performed at Macrogen USA (Rockville, Maryland, USA) and the sequences were compared to the GenBank database.

\section{RESULTS AND DISCUSSION}

The organic substrate has been known for a long time because it presents a characteristic of suppressivity against pathogens, especially of the soil, associated to the presence of different chemical compounds, and also to a direct action of the microorganisms present in it. SMS from Shiitake contains microbes and toxic compounds that can inhibit the growth of $R$. solani in tomato seedlings (Herawati; Istifadah, 2019; Suarez-Estrella et al., 2013). DGGE analysis revealed higher prokaryote abundance relative to eukaryotes, both in commercial substrate samples and in the SMS substrates of the Agaricus mushrooms (Figures 1 and 2).

Chaetomium globosum and Arthrobotrys amerospora were the predominant species among the sequenced samples of eukaryotes from the rhizosphere of seedlings obtained from A. subrufescens (Table 1).

Chaetomium globosum is a fairly abundant fungus in nature, and produces metabolites that can act on biocontrol against pathogens. Wang et al. (2012) found in this microorganism compounds like ergosterol and chaetoglobosin $\mathrm{X}$, which have antifungal activity. Hu et al. (2012) observed nematicidal activity of the substance chaetoglobosin A, produced by the fungus.

Arthrobotrys amerospora is a nematophagous fungus that has the ability to capture nematodes and other small invertebrates in the soil, also known as predatory fungus (Zhang et al., 2013). It is a desirable feature in agriculture, as many nematode species are plant parasites and can cause heavy losses.
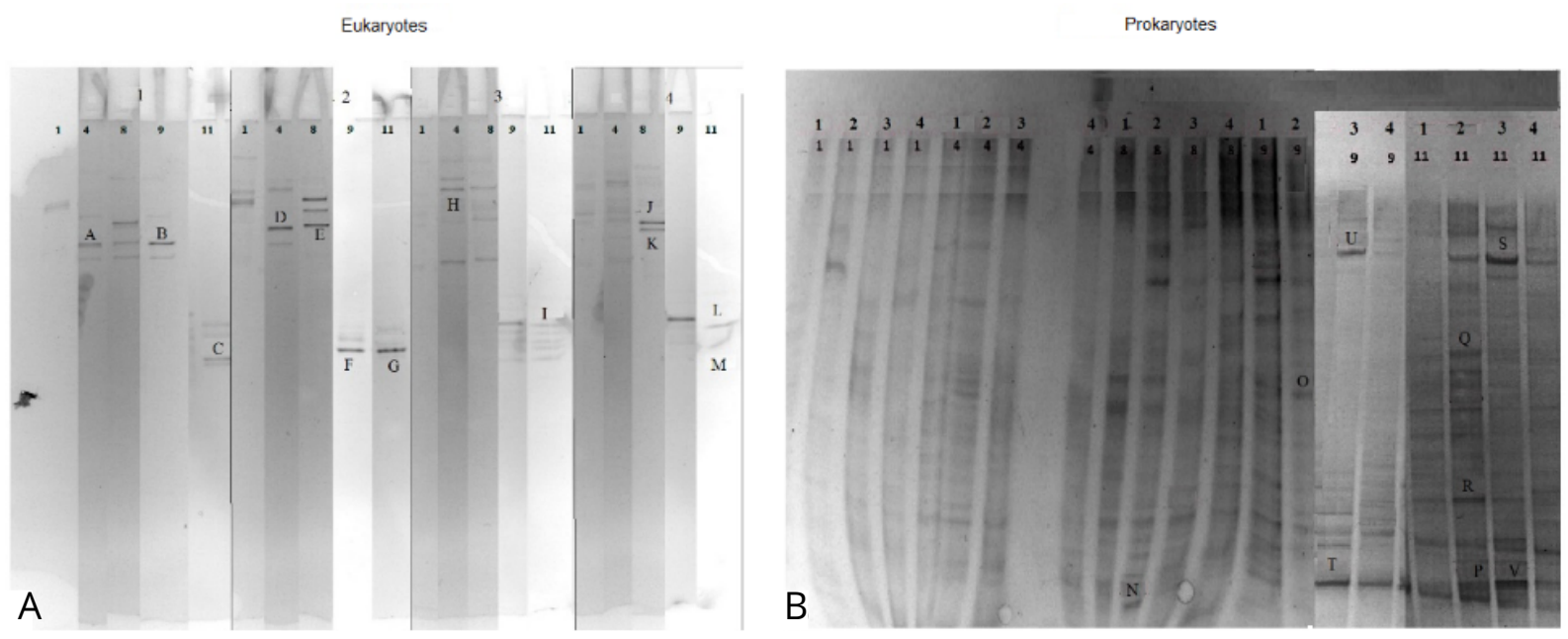

Figure 1: Pattern of DGGE bands of the rhizosphere region in tomato seedlings grown on SMS of the species Agaricus subrufescens and Agaricus bisporus, with or without commercial substrate (Tropstrato), at weeks 1, 4, 8, 9 and 11 (100\% A. subrufescens), 2 (50\% A. subrufescens + 50\% Tropstrato), 3 (100\% A. bisporus), 4 (50\% A. bisporus $+50 \%$ Tropstrato, (A)eukaryotes and prokaryotes (B). 

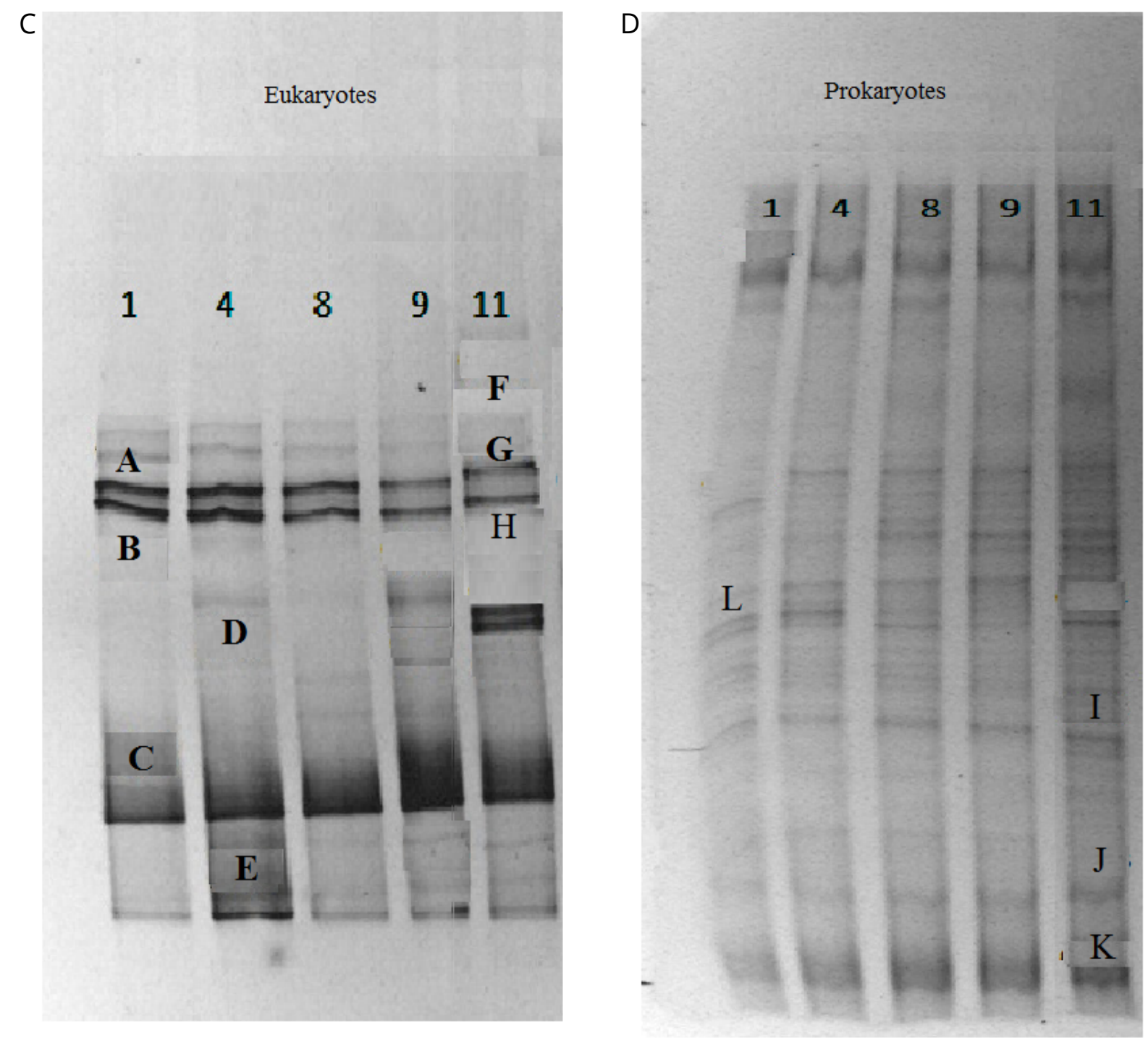

Figure 2: Pattern of DGGE bands of the rhizosphere region of tomato seedlings grown on commercial substrate (Tropstrato), over weeks 1, 4, 8, 9 and 11. Control (100\% commercial substrate [Tropstrato]), for (C) eukaryotes and (D) prokaryotes .

Among the species of fungi identified by sequencing (Table 1), the parasitoid Olpidium brassicae, known as a fungus present in the soil, infects plant roots and can be found in organic wastes in agriculture (Mikkelsen; Elphinstone; Jensen, 2006).

Another species identified was Geastrum floriforme (Table 1), which belongs to a very diverse genus with a wide range of habitats. This species was first reported in Brazil by Sousa, Baseia and Nascimento (2014). Such a late discovery in Brazil is probably due to the fact that this species does not present risks to agriculture. Pleurotus ostreatus and Pleurotus sapidus were also found in the rhizosphere of seedlings grown on substrate with SMS of $A$. bisporus (Table 1). Pleurotus is one of the most diverse genera of cultivated mushrooms, with some species capable of producing nematotoxins, secreted by hyphae, that immobilize nematodes (Cohen; Persky; Hadar, 2002). Marino and Silva (2013) showed the reduction of nematodes of the species Meloidogyne incognita in lettuce plants by $P$. ostreatus inoculated in 
the roots of the plant, proving the ability of this species to control nematodes.

The genus Chrysosporium is normally present in the soil, acting as a saprophyte with wide distribution, being a producer of metabolites such as enzymes and antimicrobials (Bohacz, 2017; Bojanich; Basualdo; Giusiano, 2018).

In samples from the rhizosphere region of tomato seedlings grown in 100\% Agaricus bisporus SMS, a similar pattern of prokaryotes is observed among all the analyzed weeks (Figure 1-B). The sequences found presented similarities with: Non-cultivable bacterium clone OTU8704, alpha non-cultivable protease EDay154M2-CL47 and Actinoplanes sp. (Table 1). The genus Actinoplanes, belonging to the actinobacteria phylum, presents some species with strong antibacterial activity (Wink et al., 2014). The actinobacterium phylum is among the largest phyla of bacteria, distributed in aquatic and terrestrial environments, including extreme environments such as deserts, which present very high or very low temperature, besides the scarcity of water, high salinity and extreme pH (Mohammadipanah; Wink, 2016). Therefore, due to their versatility, they are commonly found in compost for mushroom cultivation, since the production process of the compost favors its growth, as a result of the elevation of the temperature inside the compost pile (Souza et al., 2014). Thanks to the wealth of metabolites they produce, these microorganisms can have benefits to the plant and, therefore, it is desirable to reuse the compost, since these will probably be present.

Table 1: Nucleotide identity using Blast Database (NCBI) of sequences retrieved from DGGE bands for eukaryotes and prokaryotes. Sample of SMS from Agaricus.

\begin{tabular}{|c|c|c|c|c|c|c|c|}
\hline \multicolumn{4}{|c|}{ Eukaryotes } & \multicolumn{4}{|c|}{ Prokaryotes } \\
\hline Band & Name & Similarity & $\begin{array}{l}\text { Access } \\
\text { number }\end{array}$ & Band & Name & Similarity & $\begin{array}{l}\text { Access } \\
\text { number }\end{array}$ \\
\hline A & $\begin{array}{l}\text { Chaetomium } \\
\text { globosum }\end{array}$ & 100 & JX981455.1 & Q & $\begin{array}{l}\text { Non-cultivable bacterium } \\
\text { clone B035 }\end{array}$ & 99 & JX967611.1 \\
\hline C & $\begin{array}{l}\text { Arthrobotrys } \\
\text { amerospora }\end{array}$ & 100 & AF106533.1 & $U$ & $\begin{array}{l}\text { Non-cultivable bacterium } \\
\text { clone OTU8704 }\end{array}$ & 97 & KI791607.1 \\
\hline D & $\begin{array}{l}\text { Chaetomium } \\
\text { globosum }\end{array}$ & 100 & AB449671.1 & $\mathrm{T}$ & $\begin{array}{l}\text { Alpha non-cultivable } \\
\text { proteobacterium } \\
\text { EDay154M2-CL47 }\end{array}$ & 97 & LC017178.1 \\
\hline $\mathrm{F}$ & $\begin{array}{l}\text { Arthrobotrys } \\
\text { amerospora }\end{array}$ & 100 & AF106533.1 & $\mathrm{O}$ & $\begin{array}{l}\text { Non-cultivable bacterium } \\
\text { clone Feb08 }\end{array}$ & 96 & GU117216.2 \\
\hline G & $\begin{array}{l}\text { Arthrobotrys } \\
\text { amerospora }\end{array}$ & 100 & AF106533.1 & $P$ & $\begin{array}{l}\text { Alpha non-cultivable } \\
\text { proteobacterium } \\
\text { EDay154M2-CL47 }\end{array}$ & 95 & LC017178.1 \\
\hline 1 & $\begin{array}{l}\text { Olpidium } \\
\text { brassicae }\end{array}$ & 100 & AB205207.1 & $\mathrm{N}$ & $\begin{array}{l}\text { Non-cultivable bacterium } \\
\text { clone GCSTWT }\end{array}$ & 91 & KI776584.1 \\
\hline J & $\begin{array}{l}\text { Pleurotus } \\
\text { ostreatus }\end{array}$ & 100 & AY540325.1 & $\mathrm{R}$ & $\begin{array}{l}\text { Non-cultivable bacterium } \\
\text { clone PB17012-2CO2 }\end{array}$ & 88 & JX172031.1 \\
\hline K & $\begin{array}{l}\text { Pleurotus } \\
\text { sapidus }\end{array}$ & 100 & FJ1081.1 & V & Actinoplanes sp & 84 & EU547834.1 \\
\hline B & $\begin{array}{l}\text { Chaetomium } \\
\text { globosum }\end{array}$ & 99 & JX981455.1 & & & & \\
\hline E & $\begin{array}{l}\text { Arthrobotrys } \\
\text { amerospora }\end{array}$ & 99 & AF106533.1 & & & & \\
\hline $\mathrm{H}$ & $\begin{array}{l}\text { Geastrum } \\
\text { floriforme }\end{array}$ & 99 & KC581984.1 & & & & \\
\hline L & $\begin{array}{l}\text { Geastrum } \\
\text { floriforme }\end{array}$ & 94 & KC581984.1 & & & & \\
\hline M & $\begin{array}{l}\text { Chrysosporum } \\
\text { chyropterum }\end{array}$ & 87 & AM949570.1 & & & & \\
\hline
\end{tabular}


In the rhizosphere region of tomato plants grown on commercial substrates, the following species were found: Candida mesorugosa, Trichosporon sp., Arthrobotrys amerospora, Trichosporon mycotoxinovorans and Trichosporon asahii, in addition to a non-cultivable mycorrhizal species of the order Sebacinales (Table 2).

According to Bokati and Craven (2016), the mycorrhizal fungi from the order Sebacinales are present in most ecosystems and are associated with a large number of plants, but little is known about their role in these communities.

Candida mesorugosa is a yeast normally found in environmental samples, which has recently been classified as causing human infections (Chaves et al., 2013). No studies were found on its association with tomato or with SMS.

Trichosporon mycotoxinovorans is a yeast that has the characteristic ability to eliminate mycotoxins, such as ochratoxin A and zearalenone. El-Tarabily (2004) showed that Trichosporon asahii produces IAA (indole-3-acetic acid) and GA3 (gibberellic acid), which can improve plant growth.

For the samples of prokaryotes in the rhizosphere region of tomato plants cultivated in the commercial substrate (Tropstrato), were found: non-cultivable bacterium BUJIT6, non-cultivable Acidobacteria clone EDay84M2CL44, Aeromicrobium sp. and Caulobacter sp. (Table 2).
Acidobacteria is a recently described phylum (mid 90's), with several representatives, adapted to the most diverse environmental characteristics. Specimens of the genus Aeromicrobium produce antibiotics of the macrolide class and grow in nitrogen rich environments (Shang; Yi, 2015).

The bacterium identified as a non-cultivable EDay154M2-CL47 clone belongs to the alpha proteobacteria, belonging to the proteobacterium phylum, which includes phototrophic genera, pathogens and others that are plant symbionts, in addition to harboring species known as growth promoters in plants (Madigan et al., 2016). Although unidentified, these microorganisms may play important roles regarding to the plant. Therefore, it would be interesting to carry out more in-depth studies in order to identify them.

The results of bacterial groups identified in this work resemble those found by Ntougias et al. (2004), who also identified bacteria belonging to the divisions Proteobacteria and Actinobacteria in the SMS of Agaricaceous mushrooms. However, none of the species found by these authors was detected in the present study. One can attribute to this fact possible differences between specific raw materials used for the production of the mushroom substrate and its environmental conditions, which can significantly influence the nature of the bacterial population to colonize the SMS.

Table 2: Nucleotide identity using Blast database (NCBI) of sequences retrieved from DGGE bands for eukaryotes and prokaryotes. Commercial substrate samples (Tropstrato).

\begin{tabular}{|c|c|c|c|c|c|c|c|}
\hline \multicolumn{4}{|c|}{ Eukaryotes } & \multicolumn{4}{|c|}{ Prokaryotes } \\
\hline Band & Name & Similarity & $\begin{array}{l}\text { Access } \\
\text { number }\end{array}$ & Band & Name & Similarity & $\begin{array}{l}\text { Access } \\
\text { number }\end{array}$ \\
\hline A & Trichosporon sp & 100 & KT0033396.1 & 1 & $\begin{array}{c}\text { Non-cultivable } \\
\text { acidobacterium clone } \\
\text { EDay84M2CL44 }\end{array}$ & 96 & LC017664.1 \\
\hline B & Trichosporon sp & 100 & KT0033396.1 & K & Caulobacter sp & 95 & LCO11372.1 \\
\hline $\mathrm{F}$ & $\begin{array}{l}\text { Trichosporon } \\
\text { asahii }\end{array}$ & 100 & KT282395.1 & J & Aeromicrobium sp & 90 & KF718657.1 \\
\hline G & $\begin{array}{l}\text { Trichosporon } \\
\text { micotoxinivorans }\end{array}$ & 100 & KT132613.1 & L & $\begin{array}{c}\text { Non-cultivable bacterium } \\
\text { BUJIT6 }\end{array}$ & 95 & EU133567.1 \\
\hline $\mathrm{H}$ & $\begin{array}{l}\text { Trichosporon } \\
\text { micotoxinivorans }\end{array}$ & 100 & KT132613.1 & & & & \\
\hline E & $\begin{array}{l}\text { Trichosporon } \\
\text { micotoxinivorans }\end{array}$ & 99 & KT132613.1 & & & & \\
\hline C & $\begin{array}{l}\text { Candida } \\
\text { mesorugosa }\end{array}$ & 94 & KM382432.1 & & & & \\
\hline D & $\begin{array}{l}\text { Arthrobotrys } \\
\text { amerospora }\end{array}$ & 92 & AF106533.1 & & & & \\
\hline
\end{tabular}


Considering that the spent mushroom substrate is produced from agricultural residues such as sugarcane bagasse and other grasses such as rice straw, brachiaria and coast-cross, it can be said that most of the microorganisms identified in the present work have their origin in the raw material used in the production of the substrate. In addition, the microorganisms present in this raw material probably originated from the soil itself where they were cultivated. And finally, the SMS is accompanied by the casing layer used to manage the fruiting of the mushrooms, making this substrate even richer in terms of microbiota.

\section{CONCLUSIONS}

Different species of microorganisms were found in the rhizosphere of tomato seedlings produced in the SMS of mushrooms A. bisporus and A. subrufescens. Among the eukaryotes, Chaetomium globosum and Arthrobotrys amerospora species were predominant in the A. subrufescens SMS, and Geastrum floriforme, Chrysosporium chiropterum, Pleurotus sp., and Trichosporon sp. in the A. bisporus SMS. Some species are known as beneficial microorganisms, such as Chaetomium globosum, Arthrobotrys amerospora and Pleurotus ostreatus, which can act in the biological control of nematodes and diseases of the root system. However, species considered phytopathogen were also diagnosed in the rhizosphere of the seedlings produced in the SMS of A. bisporus, as Olpidium brassicae. Prokaryotes are the most diverse group, suggesting a large number of species not yet classified or which sequences are not yet available.

\section{ACKNOWLEDGMENTS}

The FAPEMIG (Foundation for Research Support of the State of Minas Gerais), CAPES (Coordination for the Improvement of Higher Education Personnel) and the $\mathrm{CNPq}$ (National Council for Scientific and Technological Development) are acknowledged for financial support.

\section{REFERENCES}

ASHRAFI, R. et al. Reuse of spent mushroom substrate as casing material for the production of milky white mushroom. Journal of the Bangladesh Agricultural University, 15(2):239-247, 2017.

BOHACZ, J. Biodegradation of feather waste keratin by a keratinolytic soil fungus of the genus Chrysosporium and statistical optimization of feather mass loss. World Journal of Microbiology and Biotechnology, 33(1):13, 2017.
BOJANICH, M. V.; BASUALDO, J. A.; GIUSIANO, G. In vitro effect of Chrysosporium indicum and Chrysosporium keratinophylum on Toxocara canis eggs. Revista Argentina de Microbiología, 50(3):249-254, 2018.

BOKATI, D.; CRAVEN, K. D. The cryptic Sebacinales: An obscure but ubiquitous group of root symbionts comes to light. Fungal Ecology, 22:115-119, 2016.

COLLELA, C. F. et al. Potential utilization of spent Agaricus bisporus mushroom substrate for seedling production and organic fertilizer in tomato cultivation. Ciência e Agrotecnologia, 43:e017119, 2019.

CHAVES, G. M. et al. Candida mesorugosa sp. nov., a novel yeast species similar to Candida rugosa, isolated from a tertiary hospital in Brazil. Medical Mycology, 51(3):231242, 2013.

CHIU, S. W. et al. Spent oyster mushroom substrate performs better than many mushroom mycelia in removing the biocide pentachlorophenol. Mycological Research, 102(12):1553-1562, 1998.

COHEN, R.; PERSKY, L.; HADAR, Y. Biotechnological applications and potential of wood degrading mushrooms of the genus Pleurotus. Applied Microbiology and Biotechnology, 58(5):582-594, 2002.

COUGHLAN, L. et al. Biotechnological applications of functional metagenomics in the food and pharmaceutical industries. Frontiers in Microbiology, 30(6):672, 2015.

DALLEMOLE-GIARETTA, R. et al. Pochonia chlamydosporia promotes the growth of tomato and lettuce plants. Acta Scientiarum. Agronomy, 37(4):417-423, 2015.

DONG, L. et al. Removal of $\mathrm{Cr}(\mathrm{VI})$ by surfactant modified Auricularia auricula spent substrate: Biosorption condition and mechanism. Environmental Science \& Pollution Research International, 24(21):17626-17641, 2017.

EL-TARABILY, K. A. Suppression of Rhizoctonia solani diseases of sugar beet by antagonistic and plant growth-promoting yeasts. Journal of Applied Microbiology, 96(1):69-75, 2004.

HANAFI, F. H. M. et al. Environmentally sustainable applications of agro-based spent mushroom substrate (SMS): An overview. Journal of Material Cycles and Waste Management, 20(3):1383-1396, 2018.

HIRAOKA, S.; YANG, C.; IWASAKI, W. Metagenomics and bioinformatics in microbial ecology: Current status and beyond. Microbes and Environments, 31(3):204-212, 2016. 
HERAWATI, L.; ISTIFADAH, N. The potential of spent substrate of oyster (Pleurotus ostreatus) and shiitake (Lentinula edodes) mushrooms to control damping-off disease (Rhizoctonia solani) in tomato. CROPSAVER-Journal of Plant Protection, 1:93-97, 2019.

$\mathrm{HU}, \mathrm{Y}$. et al. Nematicidal activity of chaetoglobosin a produced by Chaetomium globosum NK102 against Meloidogyne incognita. Journal of Agricultural and Food Chemistry, 61(1):41-46, 2012.

LIN, Y.; GE, X.; LI, Y. Solid-state anaerobic co-digestion of spent mushroom substrate with yard trimmings and wheat straw for biogas production. Bioresource Technology, 169:468-474, 2014.

LOPES, R. X. et al. Application of spent Agaricus subrufescens compost in integrated production of seedlings and plants of tomato. International Journal of Recycling of Organic Waste in Agriculture, 4(3):211-218, 2015.

LUBYA, E. et al. Molecular methods for assessment of antibiotic resistance in agricultural ecosystems: Prospects and challenges. Journal of Environmental Quality, 45(2):441453, 2016.

MADIGAN, M. T. et al. Brock biology of microorganisms. 14 ed., Porto Alegre: Artmed, 2016. 1006p.

MARINO, R. H.; SILVA, D. G. C. Controle de nematóide de galhas por Pleurotus ostreatus. Scientia Plena, 9(10):1-6, 2013.

MARQUES, E. L. S. et al. Spent mushroom compost as a substrate for the production of lettuce seedlings. Journal of Agricultural Science, 6(7):138-143, 2014.

MARTíNEZ-MEDINA, A. et al. Shifting from priming of salicylic acid- to jasmonic acid-regulated defences by Trichoderma protects tomato against the root knot nematode Meloidogyne incognita. New phytologist, 213(3):1363-1377, 2017.

MENG, X. et al. Composted biogas residue and spent mushroom substrate as a growth medium for tomato and pepper seedlings. Journal of environmental management, 216:62-69, 2018.

MIKKELSEN, L.; ELPHINSTONE, J.; JENSEN, D. F. Literature review on detection and eradication of plant pathogens in sludge, soils and treated biowaste: Desk study on bulk density. Bruxelles: The European Commission DG RTD under the Framework, 2006. Available in: < https://www.researchgate.net/publication/239557101_ Literature_review_on_detection_and_eradication_ of_plant_pathogens_in_sludge_soils_and_treated_ biowasteDeskstudy_on_bulk_density>. Access in: January $27,2020$.
MOHAMMADIPANAH, F.; WINK, J. Actinobacteria from arid and desert habitats: Diversity and biological activity. Frontiers in Microbiology, 6:e1541, 2016.

NTOUGIAS, S. et al. Bacterial diversity in spent mushroom compost assessed by amplified rDNA restriction analysis and sequencing of cultivated isolates. Systematic and Applied Microbiology, 27(6):746-754, 2004.

QU, J. et al. Biosorption of copper lons from aqueous solution by Flammulina velutipes spent substrate. Bioresources, 10(4):8058-8075, 2015.

RINKER, D. L. Spent mushroom substrate uses: Technology and applications. In: ZIED, D. C.; PARDO-GIMÉNEZ, A. (Eds.). Edible and medicinal mushrooms: Technology and applications. John Wiley \& Sons Ltda. 2017. 427-454p.

SHANG, S.; YI, Y. A greenhouse assay on the effect of applied urea amount on the rhizospheric soil bacterial communities. Indian Journal of Microbiology, 55(4):406-414, 2015.

SRIVASTAVA, N. et al. Analyzing functional microbial diversity: An overview of techniques. In: DAS, S.; DASH, H. Microbial diversity in the Genomic Era. 2019. 79-102p.

SOUSA, J. O.; BASEIA, I. G.; NASCIMENTO, Y. Updates on the geographic distribution of three Geastrum species from Brazilian semi-arid region. Mycosphere, 5(3):467-474, 2014.

SOUZA, T. P. et al. Analysis of thermophilic fungal populations during phase II of composting for the cultivation of Agaricus subrufescens. World Journal of Microbiology and Biotechnology, 30:2419-2425, 2014.

SUAREZ-ESTRELLA, F. et al. Biological control of plant pathogens by microorganisms isolated from agro-industrial composts. Biological Control, 67(3):509-515, 2013.

WANG, Y. et al. Bioactive metabolites from Chaetomium globosum L18, an endophytic fungus in the medicinal plant Curcuma wenyujin. Phytomedicine, 19(3-4):364-368, 2012.

WINK, J. et al. Emended description of Actinoplanes friuliensis and description of Actinoplanes nipponensis sp. nov., antibioticproducing species of the genus Actinoplanes. International Journal of Systematic and Evolutionary Microbiology, 64(2):599-606, 2014.

ZHANG, Y. et al. Genetic diversity and recombination in natural populations of the nematode-trapping fungus Arthrobotrys oligospora from China. Ecology and Evolution, 3(2):312325, 2013.

ZISOPOULOS, F. K. et al. A resource efficiency assessment of the industrial mushroom production chain: The influence of data variability. Journal of Cleaner Production, 126:394-408, 2016. 